\title{
Stem Cells and Calcium Signaling
}

\author{
Fernanda M.P. Tonelli, \\ Nanomaterials Laboratory, Department of Physics, Institute of Exact Sciences, Federal University \\ of Minas Gerais, 31270-901 Belo Horizonte, MG, Brazil
}

\section{Anderson K. Santos,}

Nanomaterials Laboratory, Department of Physics, Institute of Exact Sciences, Federal University of Minas Gerais, 31270-901 Belo Horizonte, MG, Brazil

\section{Dawidson A. Gomes,}

Department of Biochemistry and Immunology, Institute of Biological Sciences, Federal University of Minas Gerais, 31270-901 Belo Horizonte, MG, Brazil

\section{Saulo L. da Silva, Universidade Federal de São João Del Rei Campus Alto Paraopeba, 36420-000 Ouro Branco, MG, Brazil}

\section{Katia N. Gomes,}

Nanomaterials Laboratory, Department of Physics, Institute of Exact Sciences, Federal University of Minas Gerais, 31270-901 Belo Horizonte, MG, Brazil

Luiz O. Ladeira, and Nanomaterials Laboratory, Department of Physics, Institute of Exact Sciences, Federal University of Minas Gerais, 31270-901 Belo Horizonte, MG, Brazil

\section{Rodrigo R. Resende}

Nanomaterials Laboratory, Department of Physics, Institute of Exact Sciences, Federal University of Minas Gerais, 31270-901 Belo Horizonte, MG, Brazil

Rodrigo R. Resende: rrresende@hotmail.com

\section{Abstract}

The increasing interest in stem cell research is linked to the promise of developing treatments for many lifethreatening, debilitating diseases, and for cell replacement therapies. However, performing these therapeutic innovations with safety will only be possible when an accurate knowledge about the molecular signals that promote the desired cell fate is reached. Among these signals are transient changes in intracellular $\mathrm{Ca}^{2+}$ concentration $\left[\mathrm{Ca}^{2+}\right]_{\mathrm{i}}$. Acting as an intracellular messenger, $\mathrm{Ca}^{2+}$ has a key role in cell signaling pathways in various differentiation stages of stem cells. The aim of this chapter is to present a broad overview of various moments in which $\mathrm{Ca}^{2+}$ mediated signaling is essential for the maintenance of stem cells and for promoting their development and differentiation, also focusing on their therapeutic potential.

\section{Keywords}

Calcium transients; Embryonic stem cells; GPCR and RTK receptors; Calcium signaling; Stem cells differentiation

\footnotetext{
(C) Springer Science+Business Media Dordrecht 2012

Correspondence to: Rodrigo R. Resende, rrresende@hotmail . com.
} 


\section{Introduction}

Calcium $\left(\mathrm{Ca}^{2+}\right)$ is a ubiquitous intracellular signal responsible for controlling numerous cellular processes such as cell differentiation, proliferation, and apoptosis. At one level, its action is simple: cells at rest have a $\mathrm{Ca}^{2+}$ of $100 \mathrm{nM}$ but are activated when this level rises to roughly $1,000 \mathrm{nM}$. The immediate question is how can this elevation of $\mathrm{Ca}^{2+}$ concentration regulate so many processes? The answer lies in the versatility of the $\mathrm{Ca}^{2+}$ signaling mechanism in terms of speed, amplitude and spatiotemporal patterning [1].

It is well known that $\mathrm{Ca}^{2+}$ is important for cell differentiation and proliferation in mammalian somatic cells. However, $\left[\mathrm{Ca}^{2+}\right]_{\mathrm{i}}$ in stem cells has not been investigated until recent years [2-5]. This research has attracted a high interest in the field because the evidence suggests that $\mathrm{Ca}^{2+}$ signaling is related to cell proliferation and differentiation, which are important functions of stem cells. Recent studies have shown that stem cells have functional Inositol 1,4,5-trisphosphate receptor (IP3R)-regulated intracellular $\mathrm{Ca}^{2+}$ stores. They are sensitive to stimulation with ATP, histamine, and platelet-derived growth factor and depend on $\mathrm{Ca}^{2+}$ entry through store-operated channels (SOC) entry for refilling of their intracellular $\mathrm{Ca}^{2+}$ stores.

The efforts of seeking a broader understanding about these cells are justified by the promising scientific advance that they are able to provide. Besides that their use is still a very controversial topic, both in therapy (due to security in its use without the promotion of carcinogenic effect), and in research (mainly due to the source of the cells to be used in research).

Through the elucidation of the molecular mechanisms in which second messengers (such as $\mathrm{Ca}^{2+}$ ) act, the possibility of using stem cells can be improved, allowing better use of this important tool: in the repair of epithelial tissue after extensive lesions, in the treatment of degenerative diseases, in reduction on levels of immune rejection in transplantation, and even in research of mechanism of diseases, drug toxicology screening, among other purposes [6].

\section{What Are Stem Cells and How to Classify Them?}

Stem cells are unspecialized cells that can proliferate while remaining as stem cells, or adopt the process of differentiation: relying on signals received from their neighborhood. To conceptualize them two main properties are considered: their ability to promote their selfrenewal in an unlimited way and their ability to terminally differentiate into a wide variety of specific cell types [7].

The ways to classify such cells changes according to the scientific approach adopted by each group. In order to classify stem cells different classifying systems were suggested and to opt for one or other system, divide researchers' opinion. In this chapter we present a merge of the classification existing categories.

\section{A Classifying System Based on the Obtaining Source of Stem Cells}

The classification is required to reassemble the origins of pluripotent cells populations, that can be obtained from natural (blastocyst ICM (inner cell mass), niches from adult body, populations of cancer cells) or not natural sources (using cell and molecular biology as tools) (Fig. 40.1).

The stem cells derived from the ICM of blastocyst are said embryonic stem cells (ESC's): widely found in the developing embryo. Then, pluripotent stem cells can be obtained from 
in vitro fertilized (IVF): the ICM can be extracted from the blastocyst and cultured with a feeder layer.

The pluripotent stem cells that remain in niches located in specific regions of an adult body are known as adult or somatic stem cells (SSCs); they are considered remnants of the ESC's and are present in small proportions in tissues.

As will later be descript in this chapter, populations of cancer cells may include cells that dedifferentiated to a stage of stem cells, similar to the ESC's stage (the gene expression profile is similar); these are known as tumor stem cells (TSCs) [8].

There are also not natural sources to obtain stem cells through methodology that involves the transfer of nuclear contents between cells [9], cell fusion (e.g. of ESC-extract with differentiated cell) [10] or through genetic manipulation [11].

\section{A Classifying System Based on the Potency of Stem Cells}

This classification is based primarily on differences in stem cells' differentiation potential. The classes of stem cells regarding potency of cell lines are: totipotent, pluripotent, multipotent, unipotent. And some scientists also consider the omnipotent class.

Totipotent are the cells that exist from the zygote until the initial morula's blastomeres; these cells have the ability to originate any cell type. This totipotence ends before the blastocyst stage because, at this stage, it is already possible to identify two different cell types: the trophectoderm's cells and inner cell mass cells (pluripotent cells) [12]. Although omnipotent is not an universally accepted concept, there is still researchers who design this concept disagreeing with those who consider these cells totipotent. However, totipotent cells are capable of cellular self-organization (cells that have the ability to form a basic body plan through gastrulation) and omnipotent cells aren't capable of this self-organization; they are cells with the potential to generate all cell types (as well as totipotent cells), but nevertheless not necessarily these omnipotent cells must have potential for self-organization (unlike totipotent) [13].

The pluripotent ICM cells have the potential to generate many, but not all, cell types [13]. They have lost some of their differentiation potency compared to the totipotent cells.

Multipotent cells are stem cells capable of self renewal, and that can differentiate into various cell types, but these types are limited to a specific tissue, organ or system; for example, the neural multipotent stem cells can differentiate into many cell types (glial cells and neurons), but all of them belong to neural lineage of cell differentiation [13].

Unipotent cells are those capable of generating only one cell type when they adopt a differentiation route [8]. So, it is remarkable, that as the body develops from the embryonic stage of early morula to adult stage, there is a reduction in the capacity of differentiation of stem cells from an individual. That's because the genome, since the beginning of the progress of embryogenesis, becomes transcriptionally active and suffers epigenetic modifications with the passage of time; together these changes will control development since the embryonic stage until adult age.

As these changes occur, the vast majority of cells begin to originate specific transcriptomes, and differentiate into specific cell types; however, not all cells differentiate terminally.

There are still somatic stem cells (SSCs) in adults and this occurs because the stem cells can undergo changes in their genomes, but not sufficient to promote total differentiation into a 
specific cell type; these changes in the genome can, nevertheless, promote a reduction in these cells potential for differentiation.

If stem cells do not receive signals to adopt a differentiation route it can continue as stem cells maintaining potency or adopt an alternative route: apoptosis (programmed cell death) [14].

\section{Alterations on Stem Cell's Transcriptome}

The mechanisms and signaling pathways involved in controlling growth and differentiation of stem cells, are not fully elucidated. The various types of tyrosine kinase receptors (RTKs) and G protein-coupled receptor (GPCR) in the membrane of these cells allow a multitude of different ligands to join, specifically to their receptors, and trigger signaling pathways intracellularly. The different signaling pathways activated by these ligands, after integration of their individual messages, lead to a final cellular response: to maintain stem cells in their undifferentiated state, to conduct the cells to apoptosis, or cause them to adopt a route of cell differentiation. As an example of ligands that interact with these receptors there are several growth factors (as fibroblast grow factor 2 - FGF-2) and cytokines (as activin and leukemia inhibitory factor - LIF), among other signaling molecules [15].

In this chapter will be addressed some signal transduction pathways, activated by these molecules, that lead to changes in gene expression profile of stem cells inducing: cellular differentiation, or the maintenance of these cells' pluripotency.

\section{The Embryonic Stem Cells}

The interest to search and isolate pluripotent cells derived from blastocyst on preimplantation stage emerged from studies of tumors in mice gonads. In the 1960s was achieved isolation of undifferentiated cells with: remaining expansion capacity when in culture with mitotically inactivated embryonic fibroblasts (iMEF), and multi-lineage differentiation capacity; these were called embryonic carcinoma cells (ECC) [7].

From this first contact with these cells to the isolation of ESC in mice, it took more than 13 years [7]; the first human embryonic stem cells, in turn, were only isolated in the 1990s: in 1998 [8]. As mentioned earlier in this chapter, the embryonic stem cells are derived from ICM, the blastocyst cell population responsible for originating extra embryonic tissue and tissues of the whole body.

\section{How to Study ESC in Culture}

To establish and maintain ESCs with normal karyotype and the ability to fully differentiate into functional cells, scientists generally start by plating undifferentiated ESC with the supply of factors capable of maintaining them undifferentiated in the medium, but also capable of allow their proliferation. That's way onto a "feeder layer" comprised of mouse embryonic fibroblasts, in addition to supplying as-yet-unidentified support factors also supplies LIF, which prevents ESC differentiation.

In order to maintain the undifferentiated status: LIF is added to the cultivation of $\mathrm{mESC}$ (mouse embryonic stem cell), or if the cells are hESC (human embryonic stem cell), and the cellular propagation takes place using manual microdissection; this latter procedure involves the use of a Pasteur's pipette, for example, to dissect individual hESC's colony into small fragments and then transfer them to new containers with fresh culture [6].

Although, besides keeping the cell on non-differentiated stage, it is also important to promote the generation of specialized functional cells from the ESCs. However one of the 
great challenges that scientists face is to make this differentiation process be controlled and directed to a specific and unique cell type. In the following topics covered in this chapter the reader can get an overview of which are the mainly pathways that promote stem cell's differentiation into some specific cell types.

\section{induced-Pluripotent Stem Cells (iPSCs)}

The induced pluripotent stem cell (iPSC) is a kind of adult cells who suffered genetic reprogrammation to an embryonic stem cell-like state. These cells were first obtained in 2006 from mouse somatic cells [16]. In 2007, Yu et. al. reprogrammed somatic human cell nuclei to an undifferentiated state, and according to them, four factors (OCT4, SOX2, $N A N O G$, and LIN28) are sufficient to reprogram human somatic cells to pluripotent stem cells embryonic stem cells-like [17]. Since these findings, researchers are looking for new ways to generate these cells, like using adenovirus [18], bacterial artificial cromossomes [19], and recombinant proteins [20].

The possibility of iPSCs generation from somatic cells, avoids ethical difficulties on using embryonic stem cells in studies and future therapeutical applications; that is because iPSCs also have the ability to self-renew maintaining themselves undifferentiated, and to differentiate into various different cell types [21].

Today there is a large number of studies using these cells trying to understand mechanisms and to find a treatment for degenerative and genetic diseases is huge [22]. But when it comes to the therapeutic use, iPSCs are not ready to be used; however are promising. It is expected that in a near future, iPSCs will be successfully used to treat, for example, brain tumor, neurological diseases [23], and vascular diseases [10].

\section{Mechanistic Basis of Calcium Activity}

Intracellular calcium controls many cellular processes, such as fertilization, gene transcription, muscle contraction and cell death. Changes in calcium levels may occur in microseconds or hours, and can be propagated through cells and tissues [1, 24]. In the neuronal function, calcium regulates excitability, excitotoxicity, synaptic transmission, gene expression and as well as cell death [25]. Although many growth factors and neurotrophic factors can influence neuronal differentiation, diverse lines of evidence suggest that neurotransmitters, induce variations in intracellular $\mathrm{Ca}^{2+}$, which is a key regulator of differentiation. Changes in concentration of free intracellular calcium resulting from spontaneous events or from regulated cell cascades, have been shown to initiate specific courses of cell behavior in many circumstances, such as in osteo- and neuronal differentiation of mesenchymal stem cells $[26,27]$.

During advanced stages of development, intracellular calcium is involved in the induction of differentiation of individual cells. In contrast to the gradient of the calcium response for axial specification, rapid calcium increases induce differentiation, at least in neuronal and muscle cells [28]. In Xenopus, spontaneous calcium events produced by Ryanodine receptors (RYRs) during a brief period of development [29], directs differentiation of myocytes in somites. The development of neurons also is regulated by these calcium events, which control processes such as the expression of channels and specific neurotransmitters [30, 31], establishment of growth cones [32] and proper wiring of neuronal networks [33].

It should be noted, however, that the elementary events that constitute intracellular $\mathrm{Ca}^{2+}$ signaling $-\mathrm{Ca}^{2+}$ Blips or Quarks [34, 35], Puffs or Sparks [36, 37], Intracellular Waves [38] - most probably form the basis of most of all subsequent intercellular signaling events [1, 39]. It is known that $\mathrm{Ca}^{2+}$ has a regulatory function in the process of cell fate specification in 
the nervous system. For example, in spinal neurons from Xenopus embryos it was possible to identify two types of spontaneous calcium events which have been characterized both in vitro and in vivo: rapid increases of global $\left[\mathrm{Ca}^{2+}\right]_{\mathrm{i}}$ resembling action potentials, and small transient increases of calcium, called waves, which are generated in the growth cone. It has been demonstrated that global increases in calcium usually control the production of neurotransmitters and the maturation of potassium channels, while local calcium waves regulate neurite extension [30, 32]. Many of these effects of calcium are mediated by the regulation of phosphorylation of structural proteins [40]. Other effects, such as acquisition of a phenotype associated with the release of certain neurotransmitters probably require transcription [41-43].

Increases in $\left[\mathrm{Ca}^{2+}\right]_{\mathrm{i}}$ occur due to influx of $\mathrm{Ca}^{2+}$ through the plasma membrane or due to its release from intracellular stores, such as the endoplasmatic reticulum (ER) or, in muscle, from the sarcoplasmatic reticulum (SR). Calcium release from ER/SR is activated by many second messengers, among which is inositol-1,4,5-trisphosphate $\left(\mathrm{IP}_{3}\right)$ - a substance that stimulates and modulates activity of $\mathrm{IP}_{3}$ receptor which release calcium from intracellular stores $[44,45]$. When a calcium channel is opened, calcium levels increase in that region, and this micro-domain dissipates as soon as the channel is closed $[45,46]$.

The highly localized events of opening and rapidly closing calcium channels are referred to calcium sparks or puffs, depending on the nature and location of the channels. Calcium signals can appear for two purposes: for either activate processes in the micro-domain that has high calcium levels or to recruit other channels in the cell, thus promoting an increase of global $\left[\mathrm{Ca}^{2+}\right]_{\mathrm{i}}$. However, prolonged increases in $\left[\mathrm{Ca}^{2+}\right]_{\mathrm{i}}$ may be lethal, so cells use low amplitude calcium signals, or transient calcium signals, known as calcium oscillations. Cells can then use amplitude modulation (AM) or frequency modulation (FM) to decode the information contained in the calcium signal. In AM signaling, it is the amplitude of the calcium signal that initiates the cascade. This mode of signaling is generally considered less reliable than FM, leading to difficulties in detecting small increases in calcium slightly above noise levels, but cells have been shown to be able to respond to small increases in calcium [47]. In FM signaling, the frequency of calcium oscillations is used to propagate information. For example, in activated T cells it is used to optimize gene expression directed by nuclear transcription factors nuclear factors of activated T-cells (NF-AT) of the Oct/ octamer-associated protein (OAP) and of nuclear factor $\mathrm{\kappa B}(\mathrm{NF}-\kappa \mathrm{B})[48,49]$.

Calcium could also be propagated from one cell to their neighboring cells through intercellular calcium waves. The spread of calcium waves across progenitor cell populations from brain could be exemplified by radial glial cells. Radial glial cell gap junction coupling is greatest during mid-neurogenesis and decreases in late neurogenesis [50]. However, this decrease in overall cell coupling is accompanied by an increase in gap junction hemichannel-mediated $\mathrm{Ca}^{2+}$ waves. It has been shown that gap junction hemichannels mediate $\mathrm{Ca}^{2+}$ waves in the developing VZ through the release of ATP that binds to purinergic $\mathrm{P} 2 \mathrm{Y} 1$ receptors on neighboring radial glia, thereby activating an IP3-mediated release of $\mathrm{Ca}^{2+}$ from internal stores [51, 52]. Interestingly, $\mathrm{Ca}^{2+}$ wave frequency, size and distance increase in late neurogenesis [52]. The observation that similar levels and types of Cxs are expressed in mid- and late neurogenesis [53-55] suggests that Cx proteins are regulated at a molecular level such that they underlie the formation of gap junction-coupled clusters of cells during mid-neurogenesis and the hemichannel-mediated spread of $\mathrm{Ca}^{2+}$ waves during late neurogenesis.

In 2010 Resende et al. reported $\mathrm{Ca}^{2+}$ transients in $\mathrm{G} 1$ to $\mathrm{S}$ transition during cell cycle progression in diverse cell lines, including undifferentiated cells; on these cells the oscillations involve inositol 1,4,5-triphosphate receptors (IP3Rs) and L-type channels. This 
was an evidence that transients may be involved in stem cell's proliferation [56, 57]. The cell large capacity of convey a wide range of different information through a common cellular second messenger $\left(\mathrm{Ca}^{2+}\right)$, can consist in the fact that distinct variations in length, frequency and amplitude of oscillations in intracellular $\mathrm{Ca}^{2+}$ concentration, encodes for different cellular responses. Understanding the mechanisms that regulate these oscillations and the processes involved in converting its effects on cellular responses, still at large process of research and development.

Flow of cellular information requires coordinated activity of a wide network of signaling pathways. Interaction between pathways provides complex non-linear outputs for a given combination of stimuli. Examples on the density of these interactions were shown by Natarajan and his group [58]. They demonstrated that various receptors, separated or in groups are able to: mobilize calcium, initiate cyclic adenosine monophosphate (cAMP) and cytokines synthesis and also to promote phosphorylation of a variety of proteins involved in signalization. These findings suggest that different external stimuli may converge in a relatively small number of interaction mechanisms to promote signaling.

In this way growth factors, hormones and drugs elicit cellular responses in the form of $\mathrm{Ca}^{2+}$ oscillations, the frequencies of which are determined by the amount and type of the agent [59-62]. Patterns of spontaneous and stimulated $\mathrm{Ca}^{2+}$ transients drive transcription of specific genes [48, 62-64], and stimulated cAMP transients directly or through BDNF [64] also regulate gene expression $[65,66]$. It was shown that only certain bursts of $\mathrm{Ca}^{2+}$ spikes generate a cAMP increase [67]. Which can be useful in understanding the coding of gene expression by interactions between $\mathrm{Ca}^{2+}$ transients and cAMP oscillations. Higher frequencies of $\mathrm{Ca}^{2+}$ spikes have been shown to control gene expression more directly via $\mathrm{Ca}^{2+}$-dependent kinases that are not efficiently activated by low frequencies of $\mathrm{Ca}^{2+}$ transients. For example, cAMP increases induced by serotonin lead to translocation of PKA catalytic subunits into the nucleus of Aplysia neurons and gene expression underlying longterm facilitation $[66,68]$. The theoretical model combining $\mathrm{Ca}^{2+}$ oscillatory machinery and feedback regulation of cAMP synthesis, studied by Gorbunova and Spitzer [67] predicts the existence of low-frequency cAMP transients rather than high-frequency events [69, 70]. These results suggest that it could be fruitful to investigate interactions among other classes of second messengers, as tiers of messenger systems may be necessary to generate different patterns of transients that produce unique cellular responses to stimulation.

Some discussion and works involving the $\mathrm{Ga}_{\mathrm{i} / \mathrm{o}}$-coupled receptors demonstrated that, activation of this signaling pathway, generating cAMP, would lead carcinoma stem cells to differentiate into neuronal cells $[42,71]$, and neural stem cells to regulate neurite outgrowth [72].

\section{Expression Profile}

Correlations between spatial patterns of $\mathrm{Ca}^{2+}$ signaling and those of developmental gene expression represent perhaps the most exciting areas of research at present. It has been known for some time, from work with cultured cells, that $\mathrm{Ca}^{2+}$ can activate signaling pathways in both the nucleus and cytoplasm to stimulate gene expression by different pathways [73, 74], that it can function as an inhibitor as well as an activator of gene expression [75, 76], and that the frequency as well as the amplitude of $\mathrm{Ca}^{2+}$ transients is important for the regulation of gene expression [48, 76-78]. We suggest that many of the features of $\mathrm{Ca}^{2+}$-activated gene expression that are found in cultured cells might also be relevant to intact embryos. In T-cells, for example, oscillations enhance both the efficiency and specificity of signaling through the $\mathrm{Ca}^{2+}$-dependent transcription factors nuclear factor of activated T-cells (NFAT), Oct/Oap and nuclear factor kappa B (NF kappa B) in ways that are consistent with each factor's $\mathrm{Ca}^{2+}$ dependence and kinetics of activation and 
deactivation [48]. In addition, in Xenopus embryos the expression of the early neural genes $\mathrm{Zic} 3$ and geminin were shown to be downregulated when $\mathrm{Ca}^{2+}$ transients, which occurred at the right time and in the right place to be associated with neural induction, were blocked by specific L-type $\mathrm{Ca}^{2+}$-channel antagonists $[79,80]$.

The expression profile of differentiating cells can reveal key factors involved in the neuronal differentiation process. Observations based on the construction of networks from gene per gene analyses also suggest that hematopoietic sources activate multiple programs that compete subsequently with other programs, although the way in which this competition is resolved is not clear [81]. Comparisons of initial and late differentiation events reveal an increase in the number of genes differentially regulated in the latter [82]. This can be explained by multiple initiating cell lines: initial cells from the differentiation still express genes that correlate with multiple lineages, but throughout later stages of differentiation programs that are not required are inactivated, while end markers of differentiation are activated. Clearly, many late functions, such as cell cycle control and constitutive machinery, will be the same for all differentiated cells [82].

In order to understand the topology and the dynamics of transcriptional regulatory networks that control biological processes, one must focus on the following issues:

1. The identity and expression levels of overlap and interaction

2. How interactions change over time

3. The phenotypic impact of interrupting key overlaping points

The complexity of the eukaryotic transcriptional regulatory machinery reflects the many responses that it controls, but it also makes the understanding of these a networks a difficult task. This issue leads to obvious questions relates to the mechanisms through which a specific transcriptional response is triggered, including how a signaling pathway activates a transcription factor, how temporal specificity is generated, and the origins of a target.

For example, it is frequently assumed that the equilibrium state of a message RNA (mRNA) (measured in a microarray) is indicative of the rate at which transcription or even translation of a protein occurs. Moreover, it is also assumed that if a transcription factor is expressed it is active, even though dimerization, post-translational modifications and cytolocalization should also be considered. Even in the absence of knowledge about the architecture of a network it is possible to use the gene expression patterns to prove that the structural state of a complex network is natural, and to extract characteristic signatures of high dimensional stable attractor. It is not evident that such stable behavior can arise from the interactions of a large number of irregularly connected elements [83], but an important result of the analysis of discrete genetic networks is that they provide the architectural characteristics of a global network. A complex network will produce spontaneously globally coherent patterns of gene activation, such as rapid deceleration of a group of relatively small stable attractors, instead of eventually visiting all the possible states [84]. The architectural characteristics of a network known to increase the regime of ordered behavior includes:

1. Few interactions [84].

2. Preferential use of certain groups of functions for regulatory interactions between genes [84].

3. A topology without scale boundaries [85].

These characteristics have been predominant in gene and protein networks. It has been verified that differentiation of embryonic P19 cells into neurons, and of HL60 cells into neutrophils [86] does not result from a simple transition state of a bi-stable state as described 
in the traditional model $[87,88]$. Instead, cell differentiation in mammals seems to be a process of many steps in high dimension, a result which is consistent with the high connectivity of the cellular complex that sustains the regulatory genomic network. Studies in analysis revealed that differentiation is a process of many steps consistent with a model in which many keys are coupled along many states of space and dimensions, and that originates multiple stable stated which represent high dimensional attractors in the wide regulatory genomic network $[84,89]$. Such an emphasis suggests a new way of specifying the many step processes of cell differentiation in a sequence of discrete meta stable intermediaries which evade conventional analysis of elapsed time of the entire population. The existence of a multi-stable and multi-dimensional behavior during cell differentiation in mammals has important implications in the way in which differentiation is interpreted and ultimately, in how commitment of stem cells during development occurs.

\section{Major Pathways Involved in Maintaining Pluripotency of Embryonic Stem Cells in Culture}

It is known today, as a result of various studies on embryonic stem cells of mice and humans, that the Wnt/ $\beta$-catenin pathway is involved in maintaining pluripotency in both human and mice stem cells. The Wnt signaling pathway can activate a cascade of intracellular reactions triggered by the binding of Wnt proteins, and palmiltolated glycoproteins, to their receptors on the cell's membrane (Fig. 40.2).

In mouse embryonic stem cells LIF/Signal Transducer and Activator of Transcription (STAT-3), bone morphogenetic protein (BMP)/Id and LIF/phosphatidylinositol 3-kinases (PI3K)-protein kinase B (Akt) pathways are also involved in maintaining cell's pluripotency and to study their influency on mESCs pluripotence, these cells can be cultured in the presence or absence of serum [90]; when serum is present, the LIF (a serum derivative molecule) is responsible for triggering signaling pathways involving JAK, PI3K or mitogenactivated protein kinases (MAPK) [91]. In the first two situations, this molecule acts promoting the maintenance of cellular pluripotency, while in the latter situation, it induces their differentiation. In the absence of serum in cell culture, the pluripotency can be maintained through the combined addition of LIF and BMP4 into culture. As BMP4 join to its receptors, it leads to activation of Smad1, 5, 8, which in turns induce the activation of the transcription factor Id, thus maintaining the cell's pluripotency.

In hESC, the presence of LIF and BMP-4 in the culture medium is not sufficient to maintain pluripotency; according to results reported by Wei and colleagues, this fact is justified by differences in trancriptoma of murine and human cells. In human cells exogenous or cells' produced FGF-2, acts as an important signaling ligand for the maintenance of pluripotency [92]. This molecule can trigger the activation of MAPK and PI3K/Akt to do so [93]. Activin is also a ligand that leads to the maintenance of pluripotency through activation of Smad2, 3, which in turn lead to direct transcriptional activation of a gene for pluripotency: Nanog [92]. Signaling pathways that increases the expression of other genes from the transcription factors Oct4, Sox2, Klf4, cMYC and Lin28 are also relationated with promotion of pluripotency [10].

When it comes to calcium, according to Todorova et al., lysophosphatidic acid (LPA), a potent mitogen present in serum, can evoke $\mathrm{Ca}^{2+}$ mobilization from the endoplasmic reticulum through the phospholipase C (PLC) pathway on mESC. After binding to a Gprotein coupled receptor, LPA can induce the PLC activation and IP3 production. In the endoplasmatic reticulum IP3 finally stimulates $\mathrm{Ca}^{2+}$ release inducing a signaling cascade which leads to the induction of cmyc expression. Additionally, the DNA synthesis is also 
increased by this ligand on these cells: it stimulates maintenance of pluripotency and the cell proliferation [94].

\section{Wnt, Frizzled Receptors and $\mathrm{Ca}^{2+}$}

The Wnt family of glycoproteins are able to promote the activation of Frizzled (FZD) receptors, a G protein-coupled receptors [95], that are largely involved in embryonic development. The Wnt pathway, as seen earlier, is critical for maintenance of undifferentiated murine and hESC, for maintenance of large populations of these cells by stimulating their proliferation and suppressing their apoptosis.

Three possible well-characterized signaling pathways can be activated by this ligand on FZD receptors: canonical pathway-Wnt//-catenin, FZD/planar cell polarity pathway, and $\mathrm{FZD} / \mathrm{Ca}^{2+}$ pathway.

It is unclear whether the initiation of this signaling pathway involves activation of phospholipases by GPCR and/or an increase in cGMP. It is known, however, that atypical protein kinase $\mathrm{C}$ (aPKC, a.k.a. $\mathrm{PKC} \zeta)$ is activated in this signaling pathway in a $\mathrm{Ca}^{2+}$ dependent mechanism [95].

\section{Major Pathways Involved in Differentiation of Embryonic Stem Cells in Culture}

Through the MAPK pathway signaling cascade a ligand can trigger activation of cFos, cJun or Elk, thus inducing cell differentiation, and also inhibit the activity of transcription factor TBX3. This factor is responsible for activation of Nanog gene: a gene of paramount importance for the maintenance of pluripotency; then, with TBX3 inhibited the pluripotency is not maintained and the cell enters into a differentiation route [8].

In human embryonic stem cells, induction of cell differentiation can occurs through signaling triggered for the association of the ligand BMP-4 to its receptor on the cell surface; this signaling pathway involves the participation of transcription factors Smad1,5,8 [8].

Recently has been shown the involvement of REX1 on the regulation of proliferation/ differentiation of hMSCs through the suppression of p38 MAPK pathway. REX1 represses the expression of MKK3 (or MAPKK3 - an activator of p38 MAPK in hMSCs); so when it is present in high concentration, cell differentiation is suppressed and proliferation is stimulated. This marker also suppress Notch and STAT3 signaling [96].

Li et al. results showed that in mouse embryonic stem cell besides being an important transcription factor for the maintenance of an undifferentiated state, Oct 4 is also related to Erk/MAPK pathway (that is involved on ESC differentiation). Oct4, after binding of tetracycline (Tc) on surface receptors, has serine/threonine kinase 40 (Stk40) gene as a target gene and Stk40 can activate the Erk/MAPK pathway and induce extraembryonicendoderm (ExEn) differentiation in mESCs. Stk40 is also able to promote this kind of differentiation interacting with Ren2 (a calcium binding protein), which activates Erk1/2 itself [97].

\section{Somatic Stem Cells}

SSCs, or adult stem cells are found in already developed tissues and they are very rare which difficult their isolation for study. They have distinct characteristics from regular body cells due to their microenvironments and the expression of specific markers of some tissues, 
mainly related to the extracellular matrix (ECM) [98]; these cells also have the ability to generate specialized cells of other tissues, a process also known as transdifferentiation.

There are several examples of transdifferentiation of SSCs that occur naturally. The most common occurrence is probably in cancer, resulting in different types of tumors. In this case, the patterns of gene expression result in a change of morphology and behavior, contributing to carcinogenesis. However, the mechanism by which transdifferentiation is activated is still unknown, although it is of great interest for application in cellular therapies [99].

The interaction of stem cells with specific microenvironmental factors is a key mechanism in regulating the maintenance of their self-renewal and differentiation capacity. Many of the stem cells' differentiation mechanisms are analogous to the pathways that promote tumoriogenesis, which leads scientists to consider, in some cases, that the formation of a neoplasm can occur initially from stem cells [2].

There are several types of adult stem cells such as epidermal, hematopoietic, cardiac, neuronal and mesenchymal [100]. The latter are found in the stroma of organs and is therefore also known as stromal stem cells [101, 102]. In this chapter will be discussed only the main types of stem cells and their mechanism of proliferation and differentiation, focusing on the ones related to $\mathrm{Ca}^{2+}$.

\section{$\mathrm{Ca}^{2+}$ Signaling in the Process of Hematopoietic Stem Cells' Differentiation}

Among SSCs, the best characterized with regard to its mechanisms of differentiation are the hematopoietic stem cells (HSCs), found in bone marrow and umbilical cord blood.

The niche of HSCs is an anatomical unit located in the endosteum of the bone marrow cavity, which is composed of osteoblasts, osteoclasts and stromal fibroblasts, beyond others cells. In some studies it is evident the importance of osteoblasts to the development of HSCs [103]. These osteoblasts express high levels of Jagged-1, a ligand for Notch receptors.

Activation of Notch1 has been shown to result in a greater degree of self-renewal of HSCs, probably by inducing the expression of a set of self-renewal genes, including HES1.

The conditional suppression of BMPR1 also leads to increased numbers of Ncadherin ${ }^{+} \mathrm{CD} 45^{-}$osteoblastic. Thus, signaling by BMP type IA BMPR complex, regulates the population of HSCs and consequently the size of the niche. A subpopulation of murine LSK cells also expressed $\mathrm{N}$-cadherin, which interacts and forms a complex with $\beta$-catenin $[90,104]$.

Wnt proteins have been used to maintain and expand mHSCs because they are potent inducers of $\beta$-catenin signaling. It is possible that under certain conditions, some metalloproteinases such as ADAM10 cause the breakdown of membrane-bound N-cadherin, thereby increasing $\beta$-catenin cytoplasmic pool, which will now be available to work in the canonical Wnt pathway (inducing expression of target genes, including cell cycle regulatory proteins). Together with $\beta$-catenin, cMYC, cMYB, JUNB, p18 and p27 are initially responsible by proliferation and differentiation of HSCs.

HSCs are sensitive to high levels of $\mathrm{Ca}^{2+}$, mainly due to the GPCRs receptors expressed on their membranes [105]. This kind of receptor is required to maintain HSCs near to the endosteal surface of bone. The MUC1 protein can initiate $\mathrm{Ca}^{2+}$ signaling through association with its ligand ICAM-1; this suggests that MUC1 mediates cytoskeletal rearrangements to facilitate the interaction between HSC and its niches. 
Once allocated and located within the niche, cytokines, and growth factors are secreted locally and direct the fate of stem cells, initiating a cascade of intracellular signals.

Transforming growth factor- $\beta$ (TGF- $\beta$ ) is one of the few negative regulators of HSCs known. It keeps stem cells in a state of slow or idle activity partially blocking the expression of cytokine receptors on the cell surface [92]. The arrest of cell cycle regulation requires hHSCs p57. Furthermore, angiopoietin-1, produced by stromal cells, enhances HSCs capacity to become quiescent, through interaction with receptor RTKs.

FGF-1 in stem cells has the role of self-renewal and proliferation. After binding to its receptors some signaling pathways can be activated, including MAPK, STAT and PI3Ks [15]. Recent evidence indicates that members of the protein complex PCG play key role in normal hematopoiesis, and repress the expression of HOX gene in mice [106]; this HOX gene is an important regulator of differentiation pathways. However, overexpression of HOXB4 in human cells was not related to any increase in expansion or to the promotion of myeloid differentiation [107].

\section{Cardiac Stem Cells and Dependence of $\mathrm{Ca}^{2+}$ Signals}

Regenerative cardiovascular medicine hopes that it will be possible to use this type of stem cells for therapeutic purposes. However, although they have great chances of being employed in cardiac reparative therapies, it is necessary first to confirm its expansion in vitro; a clinical application may only be possible after intensive research on this expansion. The accurate control of proliferation of these cells is necessary, because their number in cardiac muscle tissue is vanishingly small [108].

In cardiac stem cells differentiation into cardiomiocytes, FGF and TGF $\beta$ factor's family are the main regulators. The activity of TAK, a protein that belongs to MAPK pathway, is stimulated by activation of TGF $\beta$ receptors. The TAK acts on the transcription factors ATF2 and CREB through the $\mathrm{Ca}^{2+}$ responsive MAPK pathway [109]. ATF2 can also bind to the Smads to promote the expression of transcription factors responsible for the development of cardiac phenotype. P42/P44 MAPK pathway (ERK) is activated by FGFs, through Ras protein [110] (Fig. 40.3).

Wnt11 also participates in the process, acting through activation of $\mathrm{Ca}^{2+}$ dependent pathway; this pathway include the participation of $\mathrm{Ca}^{2+} /$ calmodulin-dependent protein kinase (CaMK)-II, PKC and JNK [111].

Wnt proteins can also be repressors of cardiac differentiation and these proteins can be inhibited by antagonists such as Crescent and DKK1 (Dickkopf); the latter promotes differentiation into cardiomyocytes. However, Dishevelled, a mediator of the canonical pathway Wnt/ $\beta$-catenin, which implies the $\beta$-catenin and transcription factor family TCF/ LEF, has recently been used to activate CaMK pathway by PCP (planar cell polarity) [108].

\section{Neural Stem Cells and the $\mathrm{Ca}^{2+}$ Signaling}

Neural stem cells (NSCs) have the ability to guarantee the proliferation of cells in the adult nervous system, also being responsible for both the formation of neuronal and glial components. The process of neuronal differentiation, after embryonic development, is restricted to specific brain regions such as the dentate gyrus of the hippocampus and the subventricular zone (where this kind of stem cell was first identified) [112].

In development of NSCs, when these cells receives an external stimulus, often by growth factor binding to their receptors, there is an suppression on the expression of genes 
responsible for the pluripontent phenotype (mainly components of the Wnt pathway and transcription factors), whereas the genes that confer typical neurons characteristics are now widely expressed [113]. Some factors that promote neuronal differentiation, such as NeuroD, begin to act on the cell that is now differentiating.

The NeuroD binds to specific sequences of DNA when phosphorylated by CaMK (enzyme whose modulation activity is dependent on intracellular $\mathrm{Ca}^{2+}$ ) [114]. At the same time begin to be expressed neuronal cytoskeleton binding proteins such as proteins from MAP family, for example MA1B; protein that is sensitive to $\mathrm{Ca}^{2+}$

\section{Future Perspectives and Conclusions}

The use of stem cells as an alternative to treatments for diseases will change the medicine concepts currently known. The implementation of stem cells in cell substitution therapies will require a detailed understanding of the effect of growth factors on proliferation and differentiation of these cells in vitro and in vivo, particularly when it comes to be delivery to patient.

The proposed cell substitution in new clinical approaches involving the transplantation of exogenous stem cells to sites of disease, should be viewed with caution; however this promising new form of treatment should be considered due to the large potential of bring benefits to society.

Use of linear signal transduction pathways for developmental and cell differentiation control is dictated by the current information processing paradigm in cell biology lead us to rapidly reached its limits. The base of this paradigm emerged from experiments which demonstrated that soluble hormones and neurotransmitters present functional effects on cell regulation which are mediated by their binding to cell surface signaling receptors. However, more recent studies have clarified that calcium signaling pathways induced by calcium oscillations play equally important roles in the control of the cellular phenotype [27, 115-117]. Furthermore, cell shape regulates switching between different cell fates by inducing the same gene and calcium-dependent signal protein activity profiles that are activated by cell binding to specific growth factors and oscillating patterns. These observations, which can be combined with the increasing information available, but not interconnected, the processing of information within cell signaling networks emphasizes the need to build a more comprehensive and integrated model of cell regulation.

Calcium as an attractor in stem cells and progenitor cells drive the differentiation to great diversity of specialized neuronal cells and glial cells compositing a tridimensional complex cyto-architecture called brain. A great intrinsic signaling process is activated composed by neurotransmitter receptors, CaR, ROC, RYR, SOC, VOCC, NAADP or second messengers such as - DAG, 1,4,5IP3, cAMP, PIP 2 or even by modulation of kinase proteins, ERK or MAPK and enzyme, PLC. All the process is regulated by wakes and peak of calcium localized in micro-domains or in the role cell. In addition of it there are events such as amplitude and frequencies of calcium signalization. The study of the network of signalization is complex because each part of it can be involved in different levels of organization in different nets, organized around different attractors composing regulatory genetic networks which can be helpful to try understand the role process.

We suggest that further technical advances in several key areas will add greatly to our understanding. The first will be the continued development of $\mathrm{Ca}^{2+}$ reporters that can be targeted to specific cell types within a developing embryo and to subcellular compartments within these cells. There have been some encouraging advances in this area $[118,119]$. The second area for advancement will be the generation of targeted reporters that can be used as 
probes for non-invasive imaging of gene expression patterns in living embryos. Once again, advances are being made on this front. Dorsky et al. reported the development of a technique for long-term imaging of regulated gene expression in zebrafish [120]. Such probes could potentially be expressed in embryos along with a $\mathrm{Ca}^{2+}$ reporter, and their activity simultaneously (or near simultaneously) imaged. The third area to be advanced will be the continuation of the development of reporters to visualize the activation of $\mathrm{Ca}^{2+}$-sensitive targets that mediate the crosslinking between $\mathrm{Ca}^{2+}$ signals and other developmental signaling networks. Encouraging advances, such as the use of fluorescein (FL)- or green fluorescent protein (GFP)-linked calmodulin (CaM) probes [121, 122], and the development of fluorescence resonance energy transfer (FRET)-based biosensors to monitor agonistinduced phospholipase $\mathrm{C}$ activation [123], have been made in this area. The future, therefore, looks encouragingly bright for the continued exploration of developmental $\mathrm{Ca}^{2+}$ signaling.

\section{Acknowledgments}

This work was supported by Instituto Nacional de Ciência e Tecnologia de Nanomateriais de Carbono, CNPq (Conselho Nacional de Desenvolvimento Científico e Tecnológico), Brazil. R.R.R, L.O.L., K.N.G., and D.A.G. are grateful for grants from CNPq (Conselho Nacional de Desenvolvimento Científico e Tecnológico), FAPEMIG (Fundação de Amparo à Pesquisa do Estado de Minas Gerais), and CAPES (Coordenação de Aperfeiçoamento de Pessoal de Nível Superior).

\section{Abbreviations}

7TMS

Akt

AM

BDNF

BMP

BMP4

CaMK

CaR

cAMP

cGMP

CREB

DAG

DKK1

ECC

ECM

ELK

ER

ERK

ESC

ExEn 7-transmembrane segment receptor

Protein kinase B

Amplitude modulation

Brain-derived neurotrophic factor

Bone morphogenetic protein

Bone morphogenetic protein 4

Calcium/calmodulin dependent kinase protein

Calcium sensing receptor

Cyclic adenosine monophosphate

Cyclic guanosine monophosphate

Binding element responsive to cAMP

Diacylglycerol

Dickkopf 1

Embryonic carcimona cells

Extracellular matrix

Eph-related tyrosine kinase

Endoplasmatic reticulum

Extracellular-signal-regulated kinase

Embryonic stem cells

Extraembryonic endoderm 


\begin{tabular}{|c|c|}
\hline FGF & Fibroblast growth factor \\
\hline FGF1 & Fibroblast growth factor 1 \\
\hline FGF2 & Fibroblast growth factor 2 \\
\hline FL & Fluorescein \\
\hline FM & Frequency modulation \\
\hline FZD & Frizzled \\
\hline GFP & Green fluorescent protein \\
\hline GPCR & $\mathrm{G}$ protein-coupled receptor \\
\hline hESC & Human embryonic stem cell \\
\hline hHSC & Human hematopoietic stem cell \\
\hline hMSC & Human mesenchymal stem cell \\
\hline HSC & Hematopoietic stem cell \\
\hline ICM & Inner cell mass \\
\hline iMEF & Mitotically inactivated embryonic fibroblast \\
\hline IP3 & Inositol 1,4,5-triphosphate \\
\hline IP3Rs & Inositol 1,4,5-triphosphate receptors \\
\hline iPSC & Induced pluripotent stem cell \\
\hline IVF & in vitro fertilized \\
\hline JAK & Janus kinase \\
\hline Klf4 & Gut-enriched Krüppel-like factor \\
\hline LIF & Leukemia inhibitory factor \\
\hline LPA & Lysophosphatidic acid \\
\hline MKK3 & Mitogen-activated Protein Kinase Kinase 3 \\
\hline MAP & Microtubule-associated protein \\
\hline MAP1B & Protein association with the microtubule 1B \\
\hline MAP2 & Protein associated with type 2 microtubule \\
\hline МАPK & Pathways of mitogen-activated protein kinases \\
\hline МАРКК & MAP kinase kinase \\
\hline mESC & Mouse embryonic stem cell \\
\hline NAAD & Nicotinic Acid Adenine Dinucleotide \\
\hline NANOG & Nanog homeobox \\
\hline NFAT & Nuclear factors of activated T-cells \\
\hline $\mathbf{N F}_{\kappa} \mathrm{B}$ & Nuclear factor $\kappa \mathrm{Bl}$ \\
\hline NSC & Neural stem cell \\
\hline OAP & Oct/octamer-associated protein \\
\hline OCT-4 & Octamer-binding transcription factor 4 \\
\hline
\end{tabular}




$\begin{array}{ll}\text { PI3K } & \text { Phosphoinositide Kinase-3 } \\ \text { PIP2 } & \text { Phosphatidylinositol 4,5-biphosphate } \\ \text { PKA } & \text { Protein kinase A } \\ \text { PKC } & \text { Protein kinase C } \\ \text { PLC } & \text { Phospholipase C } \\ \text { PSC } & \text { Pluripotent stem cell } \\ \text { Ras } & \text { Rat sarcoma similar to G protein GTPase } \\ \text { Rcn2 } & \text { Reticulocalbin-2 } \\ \text { RyR } & \text { Ryanodine receptors } \\ \text { ROC } & \text { Receptor-operated channels } \\ \text { RTKs } & \text { Receptors tyrosine kinase } \\ \text { Stk40 } & \text { Serine/threonine kinase 40 } \\ \text { SOX2 } & \text { Sex determining region Y box 2 } \\ \text { SR } & \text { Sarcoplasmatic reticulum } \\ \text { SOC } & \text { Store-operated channels } \\ \text { SSC } & \text { Somatic stem cell } \\ \text { STAT3 } & \text { Signal transducer and activator of transcription 3 } \\ \text { Stk40 } & \text { Serine/threonine kinase 40 } \\ \text { TBX3 } & \text { T-box transcription factor } \\ \text { Tc } & \text { Tetracycline } \\ \text { TGF- } \beta & \text { Transforming growth factor- } \beta \\ \text { TSC } & \text { Tumor stem cell } \\ \text { VOCC } & \text { Voltage-operated calcium channels }\end{array}$

\section{References}

1. Berridge MJ, Lipp P, Bootman MD. The versatility and universality of calcium signalling. Nat Rev Mol Cell Biol. 2000; 1:11-21. [PubMed: 11413485]

2. Kawano S, Shoji S, Ichinose S, Yamagata K, Tagami M, Hiraoka M. Characterization of Ca(2+) signaling pathways in human mesenchymal stem cells. Cell Calcium. 2002; 32:165-174. [PubMed: 12379176]

3. Kawano S, Otsu K, Shoji S, Yamagata K, Hiraoka M. Ca(2+) oscillations regulated by Na(+)$\mathrm{Ca}(2+)$ exchanger and plasma membrane $\mathrm{Ca}(2+)$ pump induce fluctuations of membrane currents and potentials in human mesenchymal stem cells. Cell Calcium. 2003; 34:145-156. [PubMed: 12810056]

4. Li GR, Sun H, Deng X, Lau CP. Characterization of ionic currents in human mesenchymal stem cells from bone marrow. Stem Cells. 2005; 23:371-382. [PubMed: 15749932]

5. Heubach JF, Graf EM, Leutheuser J, Bock M, Balana B, Zahanich I, Christ T, Boxberger S, Wettwer E, Ravens U. Electrophysiological properties of human mesenchymal stem cells. J Physiol. 2004; 554:659-672. [PubMed: 14578475]

6. Ameen C, Strehl R, Bjorquist P, Lindahl A, Hyllner J, Sartipy P. Human embryonic stem cells: current technologies and emerging industrial applications. Crit Rev Oncol Hematol. 2008; 65:5480. [PubMed: 17689256] 
7. Friel R, van der Sar S, Mee PJ. Embryonic stem cells: understanding their history, cell biology and signalling. Adv Drug Deliv Rev. 2005; 57:1894-1903. [PubMed: 16271417]

8. Callihan P, Mumaw J, Machacek DW, Stice SL, Hooks SB. Regulation of stem cell pluripotency and differentiation by G protein coupled receptors. Pharmacol Ther. 2011; 129:290-306. [PubMed: 21073897]

9. Wakayama T, Tabar V, Rodriguez I, Perry AC, Studer L, Mombaerts P. Differentiation of embryonic stem cell lines generated from adult somatic cells by nuclear transfer. Science. 2001; 292:740-743. [PubMed: 11326103]

10. Kane NM, Xiao Q, Baker AH, Luo Z, Xu Q, Emanueli C. Pluripotent stem cell differentiation into vascular cells: a novel technology with promises for vascular re(generation). Pharmacol Ther. 2011; 129:29-49. [PubMed: 20965210]

11. Takayama N, Nishikii H, Usui J, Tsukui H, Sawaguchi A, Hiroyama T, Eto K, Nakauchi H. Generation of functional platelets from human embryonic stem cells in vitro via ES-sacs, VEGFpromoted structures that concentrate hematopoietic progenitors. Blood. 2008; 111:5298-5306. [PubMed: 18388179]

12. Niwa H. How is pluripotency determined and maintained? Development. 2007; 134:635-646. [PubMed: 17215298]

13. Denker HW. Potentiality of embryonic stem cells: an ethical problem even with alternative stem cell sources. J Med Ethics. 2006; 32:665-671. [PubMed: 17074826]

14. Leandri RD, Archilla C, Bui LC, Peynot N, Liu Z, Cabau C, Chastellier A, Renard JP, Duranthon $\mathrm{V}$. Revealing the dynamics of gene expression during embryonic genome activation and first differentiation in the rabbit embryo with a dedicated array screening. Physiol Genomics. 2009; 36:98-113. [PubMed: 19001509]

15. Suwinska A, Tarkowski AK, Ciemerych MA. Pluripotency of bank vole embryonic cells depends on FGF2 and activin A signaling pathways. Int J Dev Biol. 2010; 54:113-124. [PubMed: 20013653]

16. Takahashi K, Yamanaka S. Induction of pluripotent stem cells from mouse embryonic and adult fibroblast cultures by defined factors. Cell. 2006; 126:663-676. [PubMed: 16904174]

17. Yu J, Vodyanik MA, Smuga-Otto K, Antosiewicz-Bourget J, Frane JL, Tian S, Nie J, Jonsdottir GA, Ruotti V, Stewart R, Slukvin II, Thomson JA. Induced pluripotent stem cell lines derived from human somatic cells. Science. 2007; 318:1917-1920. [PubMed: 18029452]

18. Stadtfeld M, Maherali N, Breault DT, Hochedlinger K. Defining molecular cornerstones during fibroblast to iPS cell reprogramming in mouse. Cell Stem Cell. 2008; 2:230-240. [PubMed: 18371448]

19. Woltjen K, Michael IP, Mohseni P, Desai R, Mileikovsky M, Hamalainen R, Cowling R, Wang W, Liu P, Gertsenstein M, Kaji K, Sung HK, Nagy A. piggyBac transposition reprograms fibroblasts to induced pluripotent stem cells. Nature. 2009; 458:766-770. [PubMed: 19252478]

20. Kim JB, Sebastiano V, Wu G, Arauzo-Bravo MJ, Sasse P, Gentile L, Ko K, Ruau D, Ehrich M, van den Boom D, Meyer J, Hubner K, Bernemann C, Ortmeier C, Zenke M, Fleischmann BK, Zaehres H, Scholer HR. Oct4-induced pluripotency in adult neural stem cells. Cell. 2009; 136:411-419. [PubMed: 19203577]

21. Qin T, Miao XY. Current progress and application prospects of induced pluripotent stem cells. Yi Chuan. 2010; 32:1205-1214. [PubMed: 21513145]

22. Park IH, Arora N, Huo H, Maherali N, Ahfeldt T, Shimamura A, Lensch MW, Cowan C, Hochedlinger K, Daley GQ. Disease-specific induced pluripotent stem cells. Cell. 2008; 134:877886. [PubMed: 18691744]

23. Emdad L, D’Souza SL, Kothari HP, Qadeer ZA, Germano IM. Efficient differentiation of human embryonic and induced pluripotent stem cells into functional astrocytes. Stem Cells Dev. 2011 Not available-, ahead of print. 10.1089/scd.2010.0560

24. Bootman MD, Lipp P, Berridge MJ. The organisation and functions of local $\mathrm{Ca}(2+)$ signals. J Cell Sci. 2001; 114:2213-2222. [PubMed: 11493661]

25. Berridge MJ. Neuronal calcium signaling. Neuron. 1998; 21:13-26. [PubMed: 9697848] 
26. Sun S, Liu Y, Lipsky S, Cho M. Physical manipulation of calcium oscillations facilitates osteodifferentiation of human mesenchymal stem cells. FASEB J. 2007; 21:1472-1480. [PubMed: 17264165]

27. Gu X, Olson EC, Spitzer NC. Spontaneous neuronal calcium spikes and waves during early differentiation. J Neurosci. 1994; 14:6325-6335. [PubMed: 7965039]

28. Buonanno A, Fields RD. Gene regulation by patterned electrical activity during neural and skeletal muscle development. Curr Opin Neurobiol. 1999; 9:110-120. [PubMed: 10072371]

29. Ferrari MB, Ribbeck K, Hagler DJ, Spitzer NC. A calcium signaling cascade essential for myosin thick filament assembly in Xenopus myocytes. J Cell Biol. 1998; 141:1349-1356. [PubMed: 9628891]

30. Gu X, Spitzer NC. Distinct aspects of neuronal differentiation encoded by frequency of spontaneous Ca2+ transients. Nature. 1995; 375:784-787. [PubMed: 7596410]

31. Carey MB, Matsumoto SG. Spontaneous calcium transients are required for neuronal differentiation of murine neural crest. Dev Biol. 1999; 215:298-313. [PubMed: 10545239]

32. Gomez TM, Spitzer NC. In vivo regulation of axon extension and pathfinding by growth-cone calcium transients. Nature. 1999; 397:350-355. [PubMed: 9950427]

33. Wong RC, Pera MF, Pebay A. Role of gap junctions in embryonic and somatic stem cells. Stem Cell Rev. 2008; 4:283-292. [PubMed: 18704771]

34. Bootman M, Niggli E, Berridge M, Lipp P. Imaging the hierarchical Ca2+ signalling system in HeLa cells. J Physiol. 1997; 499(Pt 2):307-314. [PubMed: 9080361]

35. Lipp P, Niggli E. Fundamental calcium release events revealed by two-photon excitation photolysis of caged calcium in Guinea-pig cardiac myocytes. J Physiol. 1998; 508(Pt 3):801-809. [PubMed: 9518734]

36. Yao Y, Choi J, Parker I. Quantal puffs of intracellular Ca2+ evoked by inositol trisphosphate in Xenopus oocytes. J Physiol. 1995; 482(Pt 3):533-553. [PubMed: 7738847]

37. Cheng H, Lederer WJ, Cannell MB. Calcium sparks: elementary events underlying excitationcontraction coupling in heart muscle. Science. 1993; 262:740-744. [PubMed: 8235594]

38. Bootman MD, Berridge MJ. Subcellular Ca2+ signals underlying waves and graded responses in HeLa cells. Curr Biol. 1996; 6:855-865. [PubMed: 8805305]

39. Bootman MD, Berridge MJ, Lipp P. Cooking with calcium: the recipes for composing global signals from elementary events. Cell. 1997; 91:367-373. [PubMed: 9363945]

40. Lautermilch NJ, Spitzer NC. Regulation of calcineurin by growth cone calcium waves controls neurite extension. J Neurosci. 2000; 20:315-325. [PubMed: 10627609]

41. Spitzer NC, Root CM, Borodinsky LN. Orchestrating neuronal differentiation: patterns of Ca2+ spikes specify transmitter choice. Trends Neurosci. 2004; 27:415-421. [PubMed: 15219741]

42. Resende RR, Alves AS, Britto LR, Ulrich H. Role of acetylcholine receptors in proliferation and differentiation of P19 embryonal carcinoma cells. Exp Cell Res. 2008; 314:1429-1443. [PubMed: 18331729]

43. Resende RR, Gomes KN, Adhikari A, Britto LR, Ulrich H. Mechanism of acetylcholine-induced calcium signaling during neuronal differentiation of P19 embryonal carcinoma cells in vitro. Cell Calcium. 2008; 43:107-121. [PubMed: 17662384]

44. Bird GS, Putney JW Jr. Effect of inositol 1,3,4,5-tetrakisphosphate on inositol trisphosphateactivated Ca2+ signaling in mouse lacrimal acinar cells. J Biol Chem. 1996; 271:6766-6770. [PubMed: 8636098]

45. Tumelty J, Scholfield N, Stewart M, Curtis T, McGeown G. Ca2+-sparks constitute elementary building blocks for global Ca2+-signals in myocytes of retinal arterioles. Cell Calcium. 2007; 41:451-466. [PubMed: 17027081]

46. Maier LS, Zhang T, Chen L, DeSantiago J, Brown JH, Bers DM. Transgenic CaMKIIdeltaC overexpression uniquely alters cardiac myocyte $\mathrm{Ca} 2+$ handling: reduced SR Ca2+ load and activated SR Ca2+ release. Circ Res. 2003; 92:904-911. [PubMed: 12676813]

47. Dolmetsch RE, Lewis RS, Goodnow CC, Healy JI. Differential activation of transcription factors induced by Ca2+ response amplitude and duration. Nature. 1997; 386:855-858. [PubMed: 9126747] 
48. Dolmetsch RE, Xu K, Lewis RS. Calcium oscillations increase the efficiency and specificity of gene expression. Nature. 1998; 392:933-936. [PubMed: 9582075]

49. Li W, Llopis J, Whitney M, Zlokarnik G, Tsien RY. Cell-permeant caged InsP3 ester shows that $\mathrm{Ca} 2+$ spike frequency can optimize gene expression. Nature. 1998; 392:936-941. [PubMed: 9582076]

50. Lo Turco JJ, Kriegstein AR. Clusters of coupled neuroblasts in embryonic neocortex. Science. 1991; 252:563-566. [PubMed: 1850552]

51. Weissman TA, Riquelme PA, Ivic L, Flint AC, Kriegstein AR. Calcium waves propagate through radial glial cells and modulate proliferation in the developing neocortex. Neuron. 2004; 43:647661. [PubMed: 15339647]

52. Cotrina ML, Lin JH, Alves-Rodrigues A, Liu S, Li J, Azmi-Ghadimi H, Kang J, Naus CC, Nedergaard M. Connexins regulate calcium signaling by controlling ATP release. Proc Natl Acad Sci USA. 1998; 95:15735-15740. [PubMed: 9861039]

53. Kihara AH, Paschon V, Akamine PS, Saito KC, Leonelli M, Jiang JX, Hamassaki DE, Britto LR. Differential expression of connexins during histogenesis of the chick retina. Dev Neurobiol. 2008; 68:1287-1302. [PubMed: 18506822]

54. Kihara AH, Santos TO, Osuna-Melo EJ, Paschon V, Vidal KS, Akamine PS, Castro LM, Resende RR, Hamassaki DE, Britto LR. Connexin-mediated communication controls cell proliferation and is essential in retinal histogenesis. Int J Dev Neurosci. 2010; 28:39-52. [PubMed: 19800961]

55. Cina C, Bechberger JF, Ozog MA, Naus CC. Expression of connexins in embryonic mouse neocortical development. J Comp Neurol. 2007; 504:298-313. [PubMed: 17640036]

56. Resende RR, da Costa JL, Kihara AH, Adhikari A, Lorencon E. Intracellular Ca2+ regulation during neuronal differentiation of murine embryonal carcinoma and mesenchymal stem cells. Stem Cells Dev. 2010; 19:379-394. [PubMed: 19032055]

57. Resende RR, Adhikari A, da Costa JL, Lorencon E, Ladeira MS, Guatimosim S, Kihara AH, Ladeira LO. Influence of spontaneous calcium events on cell-cycle progression in embryonal carcinoma and adult stem cells. Biochim Biophys Acta. 2010; 1803:246-260. [PubMed: 19958796]

58. Natarajan K, Berk BC. Crosstalk coregulation mechanisms of G protein-coupled receptors and receptor tyrosine kinases. Methods Mol Biol. 2006; 332:51-77. [PubMed: 16878685]

59. Shen $\mathrm{P}$, Larter R. Chaos in intracellular Ca2+ oscillations in a new model for non-excitable cells. Cell Calcium. 1995; 17:225-232. [PubMed: 7621534]

60. Woods NM, Cuthbertson KS, Cobbold PH. Repetitive transient rises in cytoplasmic free calcium in hormone-stimulated hepatocytes. Nature. 1986; 319:600-602. [PubMed: 3945348]

61. Kraus M, Wolf B. Cytosolic calcium oscillators: critical discussion and stochastic modelling. Biol Signals. 1993; 2:1-15. [PubMed: 8353589]

62. Haisenleder DJ, Yasin M, Marshall JC. Gonadotropin subunit and gonadotropin-releasing hormone receptor gene expression are regulated by alterations in the frequency of calcium pulsatile signals. Endocrinology. 1997; 138:5227-5230. [PubMed: 9389505]

63. Chang LW, Spitzer NC. Spontaneous calcium spike activity in embryonic spinal neurons is regulated by developmental expression of the $\mathrm{Na}+$, K+-ATPase beta3 subunit. J Neurosci. 2009; 29:7877-7885. [PubMed: 19535599]

64. Kuczewski N, Porcher C, Ferrand N, Fiorentino H, Pellegrino C, Kolarow R, Lessmann V, Medina I, Gaiarsa JL. Backpropagating action potentials trigger dendritic release of BDNF during spontaneous network activity. J Neurosci. 2008; 28:7013-7023. [PubMed: 18596175]

65. Willoughby D, Cooper DM. Ca2+ stimulation of adenylyl cyclase generates dynamic oscillations in cyclic AMP. J Cell Sci. 2006; 119:828-836. [PubMed: 16478784]

66. Kaang BK, Kandel ER, Grant SGN. Activation of camp-responsive genes by stimuli that produce long-term facilitation in aplysia sensory neurons. Neuron. 1993; 10:427-435. [PubMed: 8384857]

67. Gorbunova YV, Spitzer NC. Dynamic interactions of cyclic AMP transients and spontaneous $\mathrm{Ca}(2+)$ spikes. Nature. 2002; 418:93-96. [PubMed: 12097913]

68. Bacskai BJ, Hochner B, Mahaut-Smith M, Adams SR, Kaang BK, Kandel ER, Tsien RY. Spatially resolved dynamics of cAMP and protein kinase A subunits in Aplysia sensory neurons. Science. 1993; 260:222-226. [PubMed: 7682336] 
69. Cooper DM, Mons N, Karpen JW. Adenylyl cyclases and the interaction between calcium and cAMP signalling. Nature. 1995; 374:421-424. [PubMed: 7700350]

70. Willoughby D, Cooper DM. Organization and $\mathrm{Ca} 2+$ regulation of adenylyl cyclases in cAMP microdomains. Physiol Rev. 2007; 87:965-1010. [PubMed: 17615394]

71. Resende RR, Britto LR, Ulrich H. Pharmacological properties of purinergic receptors and their effects on proliferation and induction of neuronal differentiation of P19 embryonal carcinoma cells. Int J Dev Neurosci. 2008; 26:763-777. [PubMed: 18675894]

72. Ciccolini F, Collins TJ, Sudhoelter J, Lipp P, Berridge MJ, Bootman MD. Local and global spontaneous calcium events regulate neurite outgrowth and onset of GABAergic phenotype during neural precursor differentiation. J Neurosci. 2003; 23:103-111. [PubMed: 12514206]

73. Bading H. Transcription-dependent neuronal plasticity the nuclear calcium hypothesis. Eur J Biochem. 2000; 267:5280-5283. [PubMed: 10951185]

74. Hardingham GE, Chawla S, Johnson CM, Bading H. Distinct functions of nuclear and cytoplasmic calcium in the control of gene expression. Nature. 1997; 385:260-265. [PubMed: 9000075]

75. Studzinski DM, Callahan RE, Benjamins JA. Increased intracellular calcium alters myelin gene expression in the N20.1 oligodendroglial cell line. J Neurosci Res. 1999; 57:633-642. [PubMed: 10462687]

76. Ferreira-Martins J, Rondon-Clavo C, Tugal D, Korn JA, Rizzi R, Padin-Iruegas ME, Ottolenghi S, De Angelis A, Urbanek K, Ide-Iwata N, D'Amario D, Hosoda T, Leri A, Kajstura J, Anversa P, Rota M. Spontaneous calcium oscillations regulate human cardiac progenitor cell growth. Circ Res. 2009; 105:764-774. [PubMed: 19745162]

77. Uhlen P, Burch PM, Zito CI, Estrada M, Ehrlich BE, Bennett AM. Gain-of-function/Noonan syndrome SHP-2/Ptpn11 mutants enhance calcium oscillations and impair NFAT signaling. Proc Natl Acad Sci USA. 2006; 103:2160-2165. [PubMed: 16461457]

78. Scemes E, Duval N, Meda P. Reduced expression of P2Y1 receptors in connexin43-null mice alters calcium signaling and migration of neural progenitor cells. J Neurosci. 2003; 23:1144411452. [PubMed: 14673009]

79. Moreau M, Neant I, Webb SE, Miller AL, Leclerc C. Calcium signalling during neural induction in Xenopus laevis embryos. Philos Trans R Soc Lond B Biol Sci. 2008; 363:1371-1375. [PubMed: 18198153]

80. Leclerc C, Webb SE, Daguzan C, Moreau M, Miller AL. Imaging patterns of calcium transients during neural induction in Xenopus laevis embryos. J Cell Sci. 2000; 113(Pt 19):3519-3529. [PubMed: 10984442]

81. Swiers G, Patient R, Loose M. Genetic regulatory networks programming hematopoietic stem cells and erythroid lineage specification. Dev Biol. 2006; 294:525-540. [PubMed: 16626682]

82. Theilgaard-Monch K, Jacobsen LC, Borup R, Rasmussen T, Bjerregaard MD, Nielsen FC, Cowland JB, Borregaard N. The transcriptional program of terminal granulocytic differentiation. Blood. 2005; 105:1785-1796. [PubMed: 15514007]

83. May RM. Will a large complex system be stable? Nature. 1972; 238:413-414. [PubMed: 4559589]

84. Kauffman, S. The origins of order: self-organization and selection in evolution. Oxford University Press; New York: 1993.

85. Aldana M, Cluzel P. A natural class of robust networks. Proc Natl Acad Sci USA. 2003; 100:8710-8714. [PubMed: 12853565]

86. Chang HH, Oh PY, Ingber DE, Huang S. Multistable and multistep dynamics in neutrophil differentiation. BMC Cell Biol. 2006; 7:11. [PubMed: 16507101]

87. Ferrell JE, Xiong W. Bistability in cell signaling: how to make continuous processes discontinuous, and reversible processes irreversible. Chaos. 2001; 11:227-236. [PubMed: 12779456]

88. Xiong W, Ferrell JE Jr. A positive-feedback-based bistable 'memory module' that governs a cell fate decision. Nature. 2003; 426:460-465. [PubMed: 14647386]

89. Huang S, Guo YP, May G, Enver T. Bifurcation dynamics in lineage-commitment in bipotent progenitor cells. Dev Biol. 2007; 305:695-713. [PubMed: 17412320] 
90. Ying QL, Nichols J, Chambers I, Smith A. BMP induction of Id proteins suppresses differentiation and sustains embryonic stem cell self-renewal in collaboration with STAT3. Cell. 2003; 115:281292. [PubMed: 14636556]

91. Niwa H, Ogawa K, Shimosato D, Adachi K. A parallel circuit of LIF signalling pathways maintains pluripotency of mouse ES cells. Nature. 2009; 460:118-122. [PubMed: 19571885]

92. Wei CL, Miura T, Robson P, Lim SK, Xu XQ, Lee MY, Gupta S, Stanton L, Luo Y, Schmitt J, Thies S, Wang W, Khrebtukova I, Zhou D, Liu ET, Ruan YJ, Rao M, Lim B. Transcriptome profiling of human and murine ESCs identifies divergent paths required to maintain the stem cell state. Stem Cells. 2005; 23:166-185. [PubMed: 15671141]

93. Dvorak P, Dvorakova D, Koskova S, Vodinska M, Najvirtova M, Krekac D, Hampl A. Expression and potential role of fibroblast growth factor 2 and its receptors in human embryonic stem cells. Stem Cells. 2005; 23:1200-1211. [PubMed: 15955829]

94. Todorova MG, Fuentes E, Soria B, Nadal A, Quesada I. Lysophosphatidic acid induces Ca2+ mobilization and c-Myc expression in mouse embryonic stem cells via the phospholipase $\mathrm{C}$ pathway. Cell Signal. 2009; 21:523-528. [PubMed: 19136060]

95. Schulte G, Bryja V. The Frizzled family of unconventional G-protein-coupled receptors. Trends Pharmacol Sci. 2007; 28:518-525. [PubMed: 17884187]

96. Bhandari DR, Seo KW, Roh KH, Jung JW, Kang SK, Kang KS. REX-1 expression and p38 MAPK activation status can determine proliferation/differentiation fates in human mesenchymal stem cells. PLoS One. 2010; 5:e10493. [PubMed: 20463961]

97. Li L, Sun L, Gao F, Jiang J, Yang Y, Li C, Gu J, Wei Z, Yang A, Lu R, Ma Y, Tang F, Kwon SW, Zhao Y, Li J, Jin Y. Stk40 links the pluripotency factor Oct4 to the Erk/MAPK pathway and controls extraembryonic endoderm differentiation. Proc Natl Acad Sci USA. 2010; 107:14021407. [PubMed: 20080709]

98. Jiang H, Grenley MO, Bravo MJ, Blumhagen RZ, Edgar BA. EGFR/Ras/MAPK signaling mediates adult midgut epithelial homeostasis and regeneration in Drosophila. Cell Stem Cell. 2011; 8:84-95. [PubMed: 21167805]

99. Batts SA, Raphael Y. Transdifferentiation and its applicability for inner ear therapy. Hear Res. 2007; 227:41-47. [PubMed: 17070000]

100. Dalby MJ, Gadegaard N, Tare R, Andar A, Riehle MO, Herzyk P, Wilkinson CD, Oreffo RO. The control of human mesenchymal cell differentiation using nanoscale symmetry and disorder. Nat Mater. 2007; 6:997-1003. [PubMed: 17891143]

101. Charbord P, Moore K. Gene expression in stem cell-supporting stromal cell lines. Ann NY Acad Sci. 2005; 1044:159-167. [PubMed: 15958709]

102. Dutt P, Wang JF, Groopman JE. Stromal cell-derived factor-1 alpha and stem cell factor/kit ligand share signaling pathways in hemopoietic progenitors: a potential mechanism for cooperative induction of chemotaxis. J Immunol. 1998; 161:3652-3658. [PubMed: 9759889]

103. de Boer J, Siddappa R, Gaspar C, van Apeldoorn A, Fodde R, van Blitterswijk C. Wnt signaling inhibits osteogenic differentiation of human mesenchymal stem cells. Bone. 2004; 34:818-826. [PubMed: 15121013]

104. Rizo A, Vellenga E, de Haan G, Schuringa JJ. Signaling pathways in self-renewing hematopoietic and leukemic stem cells: do all stem cells need a niche? Hum Mol Genet. 2006; 15(Spec No 2):R210-R219. [PubMed: 16987886]

105. Clapham DE. Calcium signaling. Cell. 2007; 131:1047-1058. [PubMed: 18083096]

106. Kajiume T, Ninomiya Y, Ishihara H, Kanno R, Kanno M. Polycomb group gene mel-18 modulates the self-renewal activity and cell cycle status of hematopoietic stem cells. Exp Hematol. 2004; 32:571-578. [PubMed: 15183898]

107. Singh V, Mueller U, Freyschmidt-Paul P, Zoller M. Delayed type hypersensitivity-induced myeloid-derived suppressor cells regulate autoreactive T cells. Eur J Immunol. 2011; 41:28712882. [PubMed: 21728175]

108. Puceat M, Jaconi M. Ca2+ signalling in cardiogenesis. Cell Calcium. 2005; 38:383-389. [PubMed: 16099501] 
109. Park JS, Kim YS, Yoo MA. The role of p38b MAPK in age-related modulation of intestinal stem cell proliferation and differentiation in Drosophila. Aging (Albany NY). 2009; 1:637-651. [PubMed: 20157545]

110. Grajales L, Garcia J, Banach K, Geenen DL. Delayed enrichment of mesenchymal cells promotes cardiac lineage and calcium transient development. J Mol Cell Cardiol. 2010; 48:735-745. [PubMed: 20060001]

111. Biteau B, Hochmuth CE, Jasper H. JNK activity in somatic stem cells causes loss of tissue homeostasis in the aging Drosophila gut. Cell Stem Cell. 2008; 3:442-455. [PubMed: 18940735]

112. Reim K, Mansour M, Varoqueaux F, McMahon HT, Sudhof TC, Brose N, Rosenmund C. Complexins regulate a late step in Ca2+-dependent neurotransmitter release. Cell. 2001; 104:7181. [PubMed: 11163241]

113. Kawano S, Otsu K, Kuruma A, Shoji S, Yanagida E, Muto Y, Yoshikawa F, Hirayama Y, Mikoshiba K, Furuichi T. ATP autocrine/paracrine signaling induces calcium oscillations and NFAT activation in human mesenchymal stem cells. Cell Calcium. 2006; 39:313-324. [PubMed: 16445977]

114. Sauka-Spengler T, Bronner-Fraser M. A gene regulatory network orchestrates neural crest formation. Nat Rev Mol Cell Biol. 2008; 9:557-568. [PubMed: 18523435]

115. Winkler DA, Burden FR, Halley JD. Predictive mesoscale network model of cell fate decisions during C. elegans embryogenesis. Artif Life. 2009; 15:411-421. [PubMed: 19463059]

116. Raff MC. Social controls on cell survival and cell death. Nature. 1992; 356:397-400. [PubMed: 1557121]

117. Evan G, Littlewood T. A matter of life and cell death. Science. 1998; 281:1317-1322. [PubMed: 9721090]

118. Baubet V, Le Mouellic H, Campbell AK, Lucas-Meunier E, Fossier P, Brulet P. Chimeric green fluorescent protein-aequorin as bioluminescent $\mathrm{Ca} 2+$ reporters at the single-cell level. Proc Natl Acad Sci USA. 2000; 97:7260-7265. [PubMed: 10860991]

119. Brini M, Pinton P, Pozzan T, Rizzuto R. Targeted recombinant aequorins: tools for monitoring $[\mathrm{Ca} 2+]$ in the various compartments of a living cell. Microsc Res Tech. 1999; 46:380-389. [PubMed: 10504215]

120. Dorsky RI, Sheldahl LC, Moon RT. A transgenic Lef1/beta-catenin-dependent reporter is expressed in spatially restricted domains throughout zebrafish development. Dev Biol. 2002; 241:229-237. [PubMed: 11784107]

121. Li CJ, Heim R, Lu P, Pu Y, Tsien RY, Chang DC. Dynamic redistribution of calmodulin in HeLa cells during cell division as revealed by a GFP-calmodulin fusion protein technique. J Cell Sci. 1999; 112(Pt 10):1567-1577. [PubMed: 10212150]

122. Torok K, Wilding M, Groigno L, Patel R, Whitaker M. Imaging the spatial dynamics of calmodulin activation during mitosis. Curr Biol. 1998; 8:692-699. [PubMed: 9637920]

123. Groth RD, Mermelstein PG. Brain-derived neurotrophic factor activation of NFAT (nuclear factor of activated T-cells)-dependent transcription: a role for the transcription factor NFATc4 in neurotrophin-mediated gene expression. J Neurosci. 2003; 23:8125-8134. [PubMed: 12954875] 


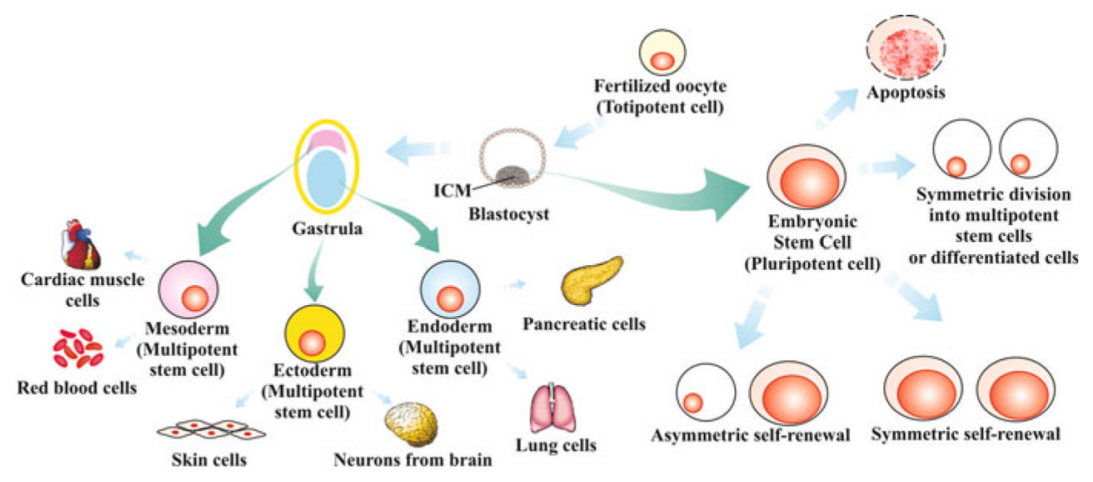

Fig. 40.1.

Origin of stem cells potency, and fates. Totipotent cells exist from the fertilized oocyte until the initial morula's blastomeres during embryo development. When these cells proliferate and specialize they originate blastocyst, which has two different cell types including ICM cells. ESCs (embryonic stem cells) that are pluripotent, derive from the ICM. After the blastocyst there is the gastrula stage which has mesoderm endoderm and ectoderm cells (multipotent stem cells). These cells can be generated by ESC differentiation and can differentiate into cells from a specific tissue. So, stem cells can proliferate in symmetric selfrenewal (diving into two identical daughter stem cells - increasing the stem cells pool) or asymmetric self-renewal (dividing into one differentiated daughter cell and one stem cell maintaining the stem cell pool), differentiate through symmetric division without selfrenewal (originating two differentiated daughter cells) and suffer apoptosis, besides staying quiescent 


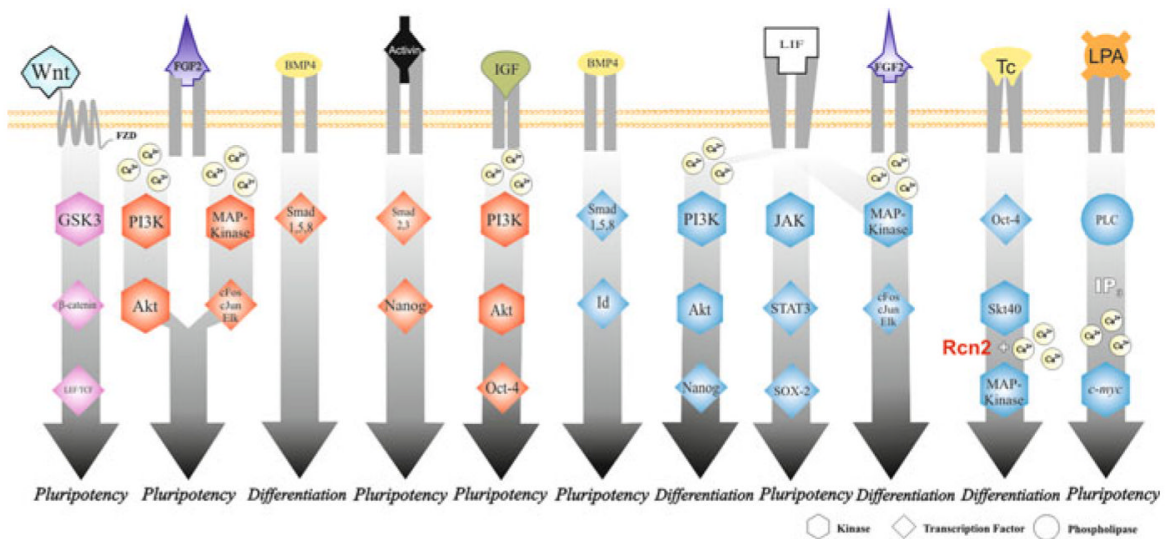

Fig. 40.2.

Major pathways involved in maintaining pluripotency of embryonic stem cells, or promoting their differentiation in culture. Pathways in blue are from mESC; those in red are from hESC. In purple are the pathways observed in both cell types 

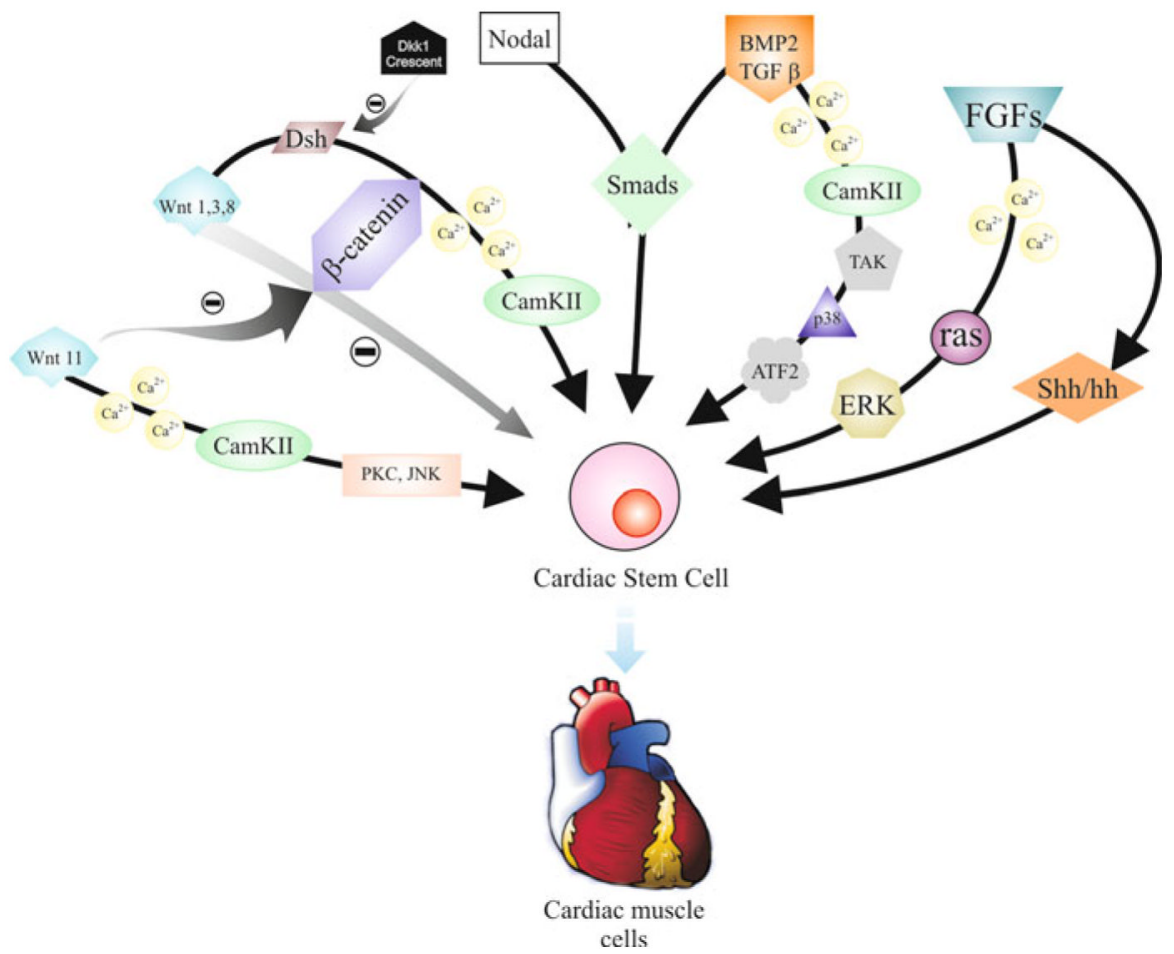

Fig. 40.3.

Major pathways involved in maintaining pluripotency of cardiac stem cells, or promoting their differentiation. See text for more information 